\title{
Review Essay \\ Defaming Public Officials: On Doctrine and Legal History
}

Robert C. Post

Norman L. Rosenberg, Protecting the Best Men: An Interpretive History of the Law of Libel. Chapel Hill: University of North Carolina Press, 1986. Pp. 369. \$29.95.

Defamation of public officials is a long-standing American tradition. Originating in a robust colonial distrust of English administration, the tradition had by the 19th century become so entrenched that Thomas Jefferson himself could complain of the "putrid state into which our newspapers have passed, and the malignity, the vulgarity, and mendacious spirit of those who write for them." Legal control over this exuberant abuse has generally been the province of the law of libel and slander, an arcane and involuted branch of the common law filled with "anomalies and absurdities for which no legal writer ever has had a kind word."2 Since the founding of the Republic there has been sharp and intense controversy over how this complex law can be reconciled with the paramount principle that elected officials in a democracy be accountable to the public. Norman Rosenberg's Protecting the Best Men is a useful and stimulating history of that controversy.

Rosenberg's work has appeared at an opportune moment. Throughout most of our national history, defamation was viewed as one of those "welldefined and narrowly limited classes of speech" that were beyond the pale of constitutional protection. ${ }^{3}$ For this reason legal restraints on the defamation of public officials were a matter of local law and varied from state to state. In 1964, however, the United States Supreme Court concluded that First Amendment values in fostering "uninhibited, robust, and wide-open" public debate and minimizing the possibilities of "self-censorship"4 justified the imposition of a uniform national rule. In New York Times Co. v. Sulli-

Robert C. Post is a professor of law at the School of Law of the University of California, Berkeley (Boalt Hall). A.B. 1969 Harvard College; J.D. 1977 Yale Law School; Ph.D. 1980 Harvard University.

1. The Writings of Thomas Jefferson 46 (Lipscomb \& Bergh, eds.) (1903) (letter to Walter Jones, Jan. 24, 1814). See J. Spear, Presidents and the Press: The Nixon Legacy 33-44 (1984).

2. W. Prosser, Handbook of the Law of Torts 737 (4th ed. 1971).

3. Chaplinski v. New Hampshire, 315 U.S. 568, 571-72 (1942). See Beauharnais v. Illinois, 343 U.S. 250 (1952).

4. New York Times Co. v. Sullivan, 376 U.S. 254, 270, 279 (1964).

(C) 1987 American Bar Foundation 
van the Court held that the Constitution precluded public officials from recovering damages for a defamatory communication ${ }^{5}$ unless it could clearly and convincingly be demonstrated that the communication "was made with 'actual malice'-that is, with knowledge that it was false or with reckless disregard of whether it was false or not."6 While there was subsequently much disagreement concerning the extent to which the "actual malice" rule should be applied to plaintiffs other than public officials, ${ }^{7}$ there was general consensus in favor of the specific holding of New York Times.

In recent years, however, that consensus has begun to unravel. Three Supreme Court Justices have explicitly called for a reconsideration of the "actual malice" rule of New York Times, even as applied to public officials. ${ }^{8}$ Journalists have attacked the rule both as providing insufficient protection for "debate about politics and public life," and as "ultimately unintelligible," discouraging dissent from a press "that has, to a degree, become unitary, powerful, and monolithic, suppressing the very diversity that it was the purpose of the First Amendment (and even of Sullivan) to protect."10 Recent empirical evidence suggests that, rather than protecting defendants from unwarranted litigation, the "actual malice" rule may paradoxically "encourage plaintiffs to sue for libel and provide an ironic sanctuary even for frivolous claims." 11 Legislators and academics have floated various re-

5. Although the precise definition of a "defamatory communication" depends on state law, in general a communication is deemed defamatory "if it tends so to harm the reputation of another as to lower him in the estimation of the community or to deter third persons from associating or dealing with him." Restatement of the Law (Second) of Torts $\S 559$ (1977).

6. New York Times, 376 U.S. at 279-80. In subsequent decisions the Court made clear that "reckless disregard" was not to be "measured by whether a reasonably prudent man would have published, or would have investigated before publishing. There must be sufficient evidence to permit the conclusion that the defendant in fact entertained serious doubts as to the truth of his publication. Publishing with such doubts shows reckless disregard for truth or falsity and demonstrates actual malice." St. Amant v. Thompson, 390 U.S. 727, 731 (1968).

The "actual malice" that a public official plaintiff must demonstrate thus turns entirely on the "state of mind of the defendant." Herbert v. Lando, 441 U.S. 153, 160 (1979). The "actual malice" requirement applies only to those defamatory communications "which might touch on an official's fitness for office." Monitor Patriot Co. v. Roy, 401 U.S. 265, 274 (1971). See Garrison v. Louisiana, 379 U.S. 64, 76-77 (1964). In addition to proving actual malice, a public official must also bear the burden of proving that the defamatory communication is false. Philadelphia Newspapers, Inc. v. Hepps, 106 Sup. Ct. 1558, 1563 (1986). Compare id. at 1570 n.10 (Stevens, J., dissenting).

7. See, e.g., Curtis Publishing Co. v. Butts, 388 U.S. 130 (1967); Rosenbloom v. Metromedia, Inc., 403 U.S. 29 (1971); Gertz v. Robert Welch, Inc., 418 U.S. 323 (1974).

8. These are Chief Justice Rehnquist, Justice White, and former Chief Justice Burger. See Dun \& Bradstreet, Inc. v. Greenmoss Builders, 472 U.S. 749, 764 (1985) (Burger, C.J., concurring); id., at 765-74 (White, J., concurring); Coughlin v. Westinghouse Broadcasting \& Cable, Inc., 106 S.Ct. 2927 (1986) (Burger, C.J., dissenting from denial of certiorari).

9. Lewis, New York Times v. Sullivan Reconsidered: Time to Return to "The Central Meaning of the First Amendment," 83 Col. L. Rev. 603, 621 (1983).

10. Adler, Annals of the Law, New Yorker, June 16, 1986, at 47; June 23, 1986, at 35.

11. Bezanson, Libel Law and the Realities of Litigation: Setting the Record Straight, 71 lowa $L$. Rev. 226, 227 (1985). The reason for this strange outcome is that a public official can always attribute the loss of a libel suit to the "actual malice" rule, and hence need never face an adverse determination concerning the truth of the underlying communication. The Iowa Libel Research Project found that public officials "see the act of initiating suit, independent of its result, as an effective and public form of reply or response" that legitimizes "their claim of falsity." Id. at 228 (emphasis added). See Bezanson, 
forms designed to eliminate the need for the "actual malice" rule in libel litigation involving public officials. ${ }^{12}$

In the midst of this turmoil, Protecting the Best Men provides a refreshing pause, a moment to reflect on the implications of two hundred years of national debate on what Rosenberg terms "the law of political libel" (at 7). Rosenberg is a skillful and entertaining guide to this debate, and the almost reassuring lesson of his work is that the issues which now roil modern reformers are neither very new nor very susceptible to definitive resolution. As with much history, one takes away the detachment and the wisdom of Ecclesiastes.

Protecting the Best Men also provides a useful occasion for assessing the relationship between law and history. While the law's misuse of history is well known, history's tendency to misperceive the internal dynamics of the law is less visible. There is a strong tendency for historians to assimilate law to general intellectual or cultural history, or, on the contrary, to view law as the outcome of deep and impersonal social forces. In either case the significance of legal doctrine is minimized. The dismissal of doctrine is reinforced by the strong attack against certain uses of doctrine mounted recently within the legal academy, as well as by the disfavor into which institutional history has fallen in the eyes of modern young historians. Protecting the Best Men exemplifies these trends, ${ }^{13}$ and as a result its treatment of political libel suffers limitations that are both important and illuminating regarding the possible relationships between law and history.

\section{I}

Protecting the Best Men paints a panoramic view of political libel in America. Rosenberg gives only cursory attention to the 17th century, but his portrait of political libel in 18th-century America is full and rich. His perspective is heavily influenced (as whose is not?) by the work of Leonard

The Libel Suit in Perspective: What Plaintiffs Want and What Plaintiffs Get, 74 Cal. L. Rev. 789 (1986).

Recent fragmentary evidence seems to indicate that the frequency of defamation suits by public officials is increasing. See Libel Defense Resource Center, LDRC Study No. 7: Public Official Libel Actions, LRDC Bull. No. 16, Mar. 15, 1986.

12. See, e.g., H.R. 2846, 99th Cong., 1st Sess. 1985 ("Schumer Bill"); S. 1979, 1985-86 Cal. Leg., Reg. Sess. (1986) ("Lockyer Bill"); Franklin, Good Names and Bad Law: A Critique of Libel Law and a Proposal, 18 U.S.F.L. Rev. 1 (1983); id., A Declaratory Judgment Alternative to Current Libel Law, 74 Cal. L. Rev. 809 (1986); Barrett, Declaratory Judgments for Libel: A Better Alternative, 74 Cal. L. Rev. 847 (1986). Most of these proposals are variations on the notion that a public official should be entitled to bring an action for a declaratory judgment, pursuant to which the truth of the defamatory communication would be determined but no damages awarded.

13. Rosenberg is quite self-conscious about this. He cautions readers at the outset "that Protecting the Best Men seeks to break from the more traditional modes of legal history," by which he means that the work is intended to examine "forces that are not distinctly legal, especially changes in political practices, in ideas of social and political order, . . . in the nature of American journalism" as well as "the changing nature of the profession of journalism and of other news-producing institutions." Id. at 7-9. Rosenberg's understanding of law has also been deeply influenced by the criticism of doctrine associated with legal realism and the Critical Legal Studies movement. 
Levy, ${ }^{14}$ but the contrast between the two historians nicely illustrates the distinctive character of Rosenberg's approach.

Both Levy and Rosenberg recognize that the 18th century was a paradoxical time, in which an "astonishing degree" of "criticism of government policies and politicians" was aired, ${ }^{15}$ and yet in which the common law crime of seditious libel was authoritatively maintained. ${ }^{16}$ But whereas Levy bypasses this "discrepancy between theory and practice" because he is "interested, to use an analogy, in defining the concept of crime, and therefore do[es] not find crime-rate statistics to be helpful,"17 Rosenberg seizes on the discrepancy in order to attack the notion of a unitary, authoritative law that excludes popular legal culture. It is this legal culture, Rosenberg argues, that "determined when and how officials could apply legal restraints to political discussion" (at 54). It was the widespread revulsion toward criminal prosecution for libel that caused its frequency to dwindle to insignificance during the 19th century, although the "crime" of libel remained solidly on the books. ${ }^{18}$

The history of political libel evidences a truly striking contrast between the stability of its doctrinal framework throughout the 19th century (and indeed up until New York Times), and the dramatic variations during that period in the actual use of political libel in the regulation of speech. Rosenberg's approach is particularly valuable because it highlights this contrast; his attempt to explain the discrepancy breaks new and fertile ground.

During the Jacksonian era, for example, libel law retained much the same doctrinal structure as in earlier years, but curiously it ceased to provide any realistic restraint on the press. Rosenberg offers several reasons to account for this discrepancy. During the Jacksonian period politicians were becoming professionals, engaged in a pluralistic competition for public office. ${ }^{19}$

14. L. Levy, Emergence of a Free Press (1985) ("Levy, Emergence"); id., Legacy of Suppression: Freedom of Speech and Press in Early American History (1960).

15. Levy, Emergence at $x$.

16. As Levy notes, the crime of seditious libel "has never been satisfactorily or consistently defined," but its general contours embraced speech "defaming or contemning or ridiculing the government: its form, constitution, officers, laws, conduct, or policies, to the jeopardy of the public peace." Id. at 8 .

In the 18 th century, libel was both a crime and a civil tort, which meant that an injured plaintiff could elect to bring either a criminal prosecution or a civil action. Truth was a defense to the tort, but at English common law it was deemed immaterial to the crime. See note 18 infra. Criminal libel was divided into four great branches: sedition, defamation, obscenity, and blasphemy. See Spencer, Criminal Libel-A Skeleton in the Cupboard (1), 1977 Crim. L. Rev. 383.

17. Levy, Emergence at $x, x v$.

18. At traditional English common law, truth provided no defense to the crime of libel, and defendants were even prohibited from presenting evidence of the truth of their communications. Even in the 18 th century Americans were distinctly uncomfortable with this doctrinal framework. The aiternative approach that gained the most widespread acceptance was that articulated by the New York Supreme Court in People v. Croswell, 3 Johnson's (N.Y.) Cases 336 (1804). The Croswell approach was eventually enacted as a New York statute providing that truth was a defense to a prosecution for libel if, but only if, the offending communication was published "with good motives and for justifiable ends." It is characteristic of Levy's approach that he views the Croswell test as having "really carried the day in the court of history until New York Times v. Sullivan." Levy, Emergence at xix.

19. Wilentz, On Class and Politics in Jacksonian America, 10 Revs. in Am. His., Dec. 1982, at $55-57$. 
Disagreement over public policy had come to be accepted as inherent in the political process. In such a context the concept of sedition made no sense, and personal defamation was accepted as a necessary aspect of political warfare, particularly since from about the 1820 s through the 1870 s most American newspapers were closely tied to political organizations. As one Whig partisan remarked, political campaigns were like mudslinging contests that always contained enough dirt to "make at least one good sized mountain, and some half-dozen hills besides, under which numerous unfortunate candidates lie buried." The successful politicians, however, "either crawl, or are at least dug out by their friends; when after a little recollection, refreshment and breathing, they reengage in the contest, with unabated spirit and undiminished fury." 20

This attitude toward political defamation can in part be explained by the intense egalitarianism of the antebellum period, in which public opinion reigned supreme. Recourse to the courts was viewed as an illegitimate attempt to avoid democratic judgment, and the plaintiff who attempted to find vindication by bringing a lawsuit was apt instead to find himself vilified as an un-American elitist. Thus James Fenimore Cooper, who in 1837 unleashed an unprecedented barrage of civil and criminal libel suits precisely to restrain what he viewed as the malicious tyranny of public opinion, found himself damned in the end because, as a contemporary journal put it, to "carry a controversy from the press into the law is to acknowledge . . . the superiority of the courts of judicature to the high court of Public Opinion."21

In the years after the Civil War, however, when the nation receded from its Jacksonian faith in public opinion, ${ }^{22}$ the law of libel revived as a significant restraint on the press. The frequency of libel suits increased dramatically. During the 1884 presidential campaign, for example, Joseph Pulitzer's New York World was named as the defendant in 21 libel suits. Rosenberg argues that this transformation must be understood in the context of the changing nature of the American press. By the Gilded Age most newspapers had become independent of political parties. They were dependent instead upon advertising revenues, which were keyed to expanding circulation. Many newspapers responded by emphasizing sensationalism and entertainment, by "opening up all kinds of areas of hitherto private life, including family affairs and sexual morality, to constant . . . scrutiny" (at 187). The result was to place the question of political libel in an entirely new light.

20. The Newspaper Press, Am. Rev. 2 (n.s. 1848): 564-99, at 597 (quoted in Rosenberg at 143-44). Rosenberg does not make clear whether this mutual forbearance rested on an implicit understanding concerning the kinds of defamatory allegations that were appropriate to political struggle, or whether it rested instead on a common interest in keeping the political press free from judicial oversight.

21. New Yorker, Feb. 23, 1839, reprinted in E. Outland, The 'Effingham' Libels on Cooper 82 (1929).

22. See G. Fredrickson, The Inner Civil War (1965). 
Rosenberg nicely illustrates the point through a discussion of the developing legal positions of Thomas Cooley. In his early and influential treatise, Constitutional Limitations (1868), Cooley viewed the law of political libel as antagonistic to the principles of democratic accountability. His concern was chiefly with the civil tort of libel, since by the time of the Civil War criminal prosecutions for libel had virtually vanished. ${ }^{23}$ Although truth was an affirmative defense to the tort, publishers of defamatory communications were subject to strict liability; any mistake, however innocent, would subject them to liability.

Cooley viewed the tort as stifling for the kind of public debate necessary for political democracy. He therefore proposed that defamation law contain a conditional privilege which, as he later formulated it in his Treatise on the Law of Torts, would provide an exemption "from liability for any publication made in good faith, and in the belief in its truth, the making of which, if true, would be justified by the occasion." 24 He specifically contemplated that the privilege would apply to discussion of the "character and official conduct of one holding a public office," to the evaluation of "the character, the habits, and mental and moral qualifications of any person presenting himself . . . as a candidate for a public office," and, more generally, to all communications "where the matter discussed is one of general public interest." $25 \mathrm{He}$ anticipated that the principal beneficiary of the proposed privilege would be the press, whose "chief importance . . . from a constitutional point of view" was that it enabled "the citizen to bring any person in authority, any public corporation or agency, or even the government in all its departments, to the bar of public opinion, and to compel him or them to submit to an examination and criticism of conduct, measures, and purposes in the face of the world, with a view to the correction or prevention of evils." 26

Very few courts accepted the conditional privilege advocated by Cooley, the most notable exception being the Kansas Supreme Court in the case of Coleman v. MacLennan, ${ }^{27}$ which would eventually provide a doctrinal re-

23. Rosenberg reports that during the period from 1865 to 1876 there were fewer than 20 reported libel prosecutions in the entire country, and that in previous decades there were likewise "a relatively small number of criminal libel prosecutions." Id. at 156 \& n. 10.

24. T. Cooley, A Treatise on the Law of Torts 218 (1880) ("Cooley, Torts").

25. Id.

26. T. Cooley, The General Principles of Constitutional Law 274 (1880). In Cooley's view the law should take account of the technology underlying the newspaper industry, as, for example, the fact that news often came from "telegraph dispatches," and that therefore "the publisher can have no knowledge concerning it, and no inquiries which he could make would be likely to give him more definite information, unless he delays the publication until it ceases to be of value to his readers." Cooley, A Treatise on Constitutional Limitations 454 (1868) ("Cooley, Constitutional Limitations"). Cooley noted in truly prescient fashion that "The railway has become the successor of the king's highway, and the plastic rules of the common law have accommodated themselves to the new condition of things; but the changes accomplished by the public press seem to have passed unnoticed in the law, and, save only where modifications have been made by constitution or statute, the publisher of the daily paper occupies to-day the position in the courts that the village gossip and retailer of scandal occupied two hundred years ago, with no more privilege and no more protection." Id. at 452.

27. 78 Kan. 711,98 P. 281 (1908). 
source for New York Times v. Sullivan. ${ }^{28}$ Indeed Cooley himself began to retreat from his own suggestions. Faced with an independent and aggressively commercial press, he ruled as a Justice of the Michigan Supreme Court that " $\mathrm{A}$ false and injurious publication made in a public journal for 'sensation and increase of circulation' is unquestionably in the legal sense malicious." 29 Thus defamatory communications by newspapers that were run for a profit and that were unaffiliated with political organizations were liable to be viewed as made in bad faith and unprivileged.

The change in Cooley's perspective was fundamental. Although the press had earlier appeared to him to be an extension of the democratic citizenry, ${ }^{30}$ it now appeared to him to have acquired its own separate and distasteful corporate existence. The "bar of public opinion" dissolved into an image of passive and manipulated newspaper readers. The symbolic coup de grâce occurred in 1906, when the third edition of Cooley's Treatise on Torts, edited by John Lewis, sharply truncated the scope of the proposed conditional privilege in the context of political libel: "[A] candidate for public office does not surrender his private character to the public and he has the same remedy as before. And the publication of false and defamatory statements concerning him, whether relating to his private character or public acts, are not privileged." 31

After Cooley's retreat, there was no great push to alter the doctrinal framework of political libel until New York Times constitutionalized the area in 1964. In 1937 the American Law Institute confidently rejected an effort by Fowler Harper and others to incorporate into the Restatement of the Law of Torts a conditional privilege for defamatory statements about public officials and candidates. Augustus Hand denounced the proposed privilege as "a dangerous and unwarranted departure from the whole doctrine of libel," and as "revolutionary and . . . warranted by no public policy" (quoted in Rosenberg at 220).

Despite the strictness of libel doctrines, Rosenberg notes that after World War I "there was a considerable gap between tough-looking libel laws and

28. By the turn of the century most states provided a conditional privilege for statements of opinion on matters of public concern, but no privilege at all for the publication of false defamatory facts. The leading decision in this regard was Burt v. Advertiser Newspaper Co., 154 Mass. 238, 28 N.E. 1 (1891) (per Oliver Wendell Holmes).

29. MacLean v. Scripps, 52 Mich 250, 253, 18 N.W. 209, 210 (1884).

30. "Every party has its newspaper organs; every shade of opinion on political, religious, literary, moral, industrial, or financial questions has its representative; every locality has its press to advocate its claims, and advance its interests . . . Cooley, Constitutional Limitations at 452.

31. 1 T. Cooley, A Treatise on the Law of Torts 443 (3d. 1906) (J. Lewis ed.). By contrast, in 1868 Cooley had explicitly criticized the "assumption, that the private character of a public officer is something aside from, and not entering into or influencing, his public conduct, and that a thoroughly dishonest man may be a just minister. Any such assumption is false to human nature, and the public have a right to assume that a corrupt life will influence public conduct, however plausibly it may be glossed over. They are, therefore, interested in knowing what the character of their public servants is, as well as that of persons offering themselves for their suffrages. If so, it would seem that there should be some privilege of comment; that that privilege could only be limited by good faith and just intention." Cooley, Constitutional Limitations at 440 . 
the ability of plaintiffs to invoke them successfully" (at 222). Rosenberg attributes this gap to the corporate maturity of the press, which had acquired the resources and legal expertise to overwhelm most potential plaintiffs. Experienced press attorneys could turn to their advantage ancient intricacies of defamation law that could only baffle their unsophisticated opponents. As a result the attitude of the press was that defamation law "works well although it looks bad on paper," as the managing editor of a metropolitan New York newspaper told Zechariah Chafee in 1947.32

It is striking that in the years between World War I and the New York Times decision, the 19th-century tradition identified by Rosenberg, which viewed the law of political libel as central to the meaning and scope of the constitutional guarantee of freedom of speech, essentially disappeared. During that period legal scholars and their casebooks relegated political libel to the realm of private law. As recently as 1952 Harry Kalven could remark on how unfashionable it had been "to mention free speech and defamation together in recent years." ${ }^{33}$ Part of the reason for this separation was the acquiescence of the organized press. At a time when journalists were struggling to legitimate the concept of "professional" journalism, defamation law began to be perceived as a useful means of distinguishing professional from unprofessional reporting. Part of the reason also was that by the 20th century criminal defamation was simply a historical curiosity, and the law of sedition had lost all analytic connection to the problem of defamation. Thus in the Supreme Court's consideration of the Sedition Act of 1918, which prompted Oliver Wendell Holmes to reevaluate the constitutionality of the Alien and Sedition Acts of 1798 and to rethink the famous "clear and present danger" test, ${ }^{34}$ the tort of civil defamation simply had no place.

New York Times Co. v. Sullivan, of course, changed all that by dramatically reuniting the constitutional issues posed by sedition and civil defamation, and by deeply reordering the doctrinal framework of political libel. Unfortunately Rosenberg has relatively little to say about New York Times and its subsequent history. He mentions the contemporary resurgence of investigative journalism, the recent inflation of jury verdicts in defamation cases, and the rise of television journalism; but his discussion seems aimless and unfocused. He eschews policy recommendations, apparently taking the view that robust and vigorous public debate depends on "nonlegal pressures from within the communications industry itself and . . . [upon] the complex links between the Fourth Estate and other powerful institutions, especially those of the cold-war security state," rather than upon the effects "of formal, governmentally enforced restrictions" such as defamation law (at 264).

32. Z. Chafee, 1 Government and Mass Communications 103 (1947).

33. Kalven, The Law of Defamation and the First Amendment, in Conference on the Arts, Publishing, and the Law 4 (Law School, University of Chicago, May 5, 1952).

34. Abrams v. United States, 250 U.S. 616 (1919). 


\section{II}

Rosenberg's disappointing discussion of New York Times is no accident. In his view the primary significance of the case is that it illustrates "the problems with liberal boundary theory":

This theory, applied to libel law, rested upon the proposition that judges could objectively find the line, somewhere within the common law tradition, that separated protected from unprotected speech, the speaker/publisher's right of expression from the public official/plaintiff's right to reputation, the freedom to speak from the security for another's good name. (At 262)

But Rosenberg's diagnosis is quite mistaken, for "liberal boundary theory" has virtually no application to New York Times and its progeny. These are cases that exemplify the progressive tradition of flexibly using law to attain public policy goals, rather than of objectively carving nature at her joints through the enunciation of abstract and doctrinaire rules. ${ }^{35}$ That Rosenberg could have so mischaracterized New York Times is illustrative of a grave underlying weakness of Protecting the Best Men, which is its unsteady grasp of the theory and practice of the law. ${ }^{36}$

One has the vague but distinct impression that at bottom Rosenberg views legal doctrine, like "liberal boundary theory," as a "dubious" enterprise. ${ }^{37}$ This perhaps accounts for Rosenberg's failure to take the history of libel doctrine very seriously, and for his tendency to overlook doctrinal developments that are obviously relevant to the issues raised by Protecting the Best Men. The distinction between fact and opinion, for example, has been used by both common and constitutional law as a primary means of regulating political libel, ${ }^{38}$ and yet it is mentioned by Rosenberg in only the most perfunctory fashion. He ignores the developing doctrine of neutral reportage, although the doctrine is meant to address precisely the concerns articulated by Thomas Cooley over one hundred years ago. ${ }^{39}$ And he does not

35. For a discussion of the contrast between the progressive and liberal traditions, see Gordon, Legal Thought and Legal Practice in the Age of American Enterprise, 1870-1920, in Professions and Professional Ideologies in America (G. Geison ed. 1983).

36. The work contains occasional inaccuracies. Contrary to Rosenberg's assertion, for example, allegations of "unchastity in a woman" did not under English common law fall into "the category of 'slander per se." " Rosenberg at 274 n.12. See Pollard v. Lyon, 91 U.S. 225 (1875). In Bindrim v. Mitchell the "Supreme Court" did not, as claimed by Rosenberg, give "the general literary community" an unanticipated jolt by announcing a new rule of law. Bindrim was decided by a lower California court and broke no new doctrinal ground. See Rosenberg at 256; Bindrim v. Mitchell, 92 Cal. App. 3d 61, 155 Cal. Rptr. 29, cert. denied, 444 U.S. 984 (1979); Schauer, Liars, Novelists, and the Law of Defamation, 51 Brook. L. Rev. 233, 234 (1985).

37. Rosenberg at 262; see id. at 266.

38. See, e.g., Restatement of Torts $\$ \S 606-7$ (1938); Pulvermann v. A.S. Abell Co., 228 F.2d 797 (4th Cir. 1956); Ollman v. Evans, 750 F.2d 970, 993-1001 (D.C. Cir. 1984) (Bork J., concurring), cert. denied, 471 U.S. 1127 (1985). See note 28 supra.

39. The doctrine of neutral reportage is designed to create a constitutional privilege for the accurate and disinterested reporting of serious charges made against public figures in the context of a public controversy. See Edwards v. National Audubon Society, 556 F.2d 113 (2d Cir.), cert. denied sub nom. Edwards v. New York Times Co., 434 U.S. 1002 (1977); Barry v. Time, Inc., 584 F.Supp. 1110 (N.D. Cal. 1984); Note, The Developing Privilege of Neutral Reportage, 69 Va. L. Rev. 853 (1983). Under common law doctrine, those who repeat a defamatory communication are as liable as the person who 
discuss the emergence of the uniquely American distinction between libel per se and libel per quod, even though the distinction is an apparent although somewhat clumsy effort to respond to technological innovations in the organized press..$^{40}$

Rosenberg's relative indifference to doctrine has subtle but important consequences. It limits his understanding of how and why individuals have historically decided to use the legal process to redress their injured reputations. One must grasp the intricate and evolving relationship between substantive rules of political libel and ancillary rules of evidence and procedure in order to apprehend the changing shape and experience of actual libel litigation. It would presumably make a great deal of difference to a potential libel plaintiff whether he will be permitted to prove the falsity of the libelous communication, ${ }^{41}$ or whether he or the defendant will be permitted to testify on their own behalf, ${ }^{42}$ or whether the defendant will be permitted to introduce evidence of the plaintiff's poor reputation in mitigation of damages. ${ }^{43}$ Yet Rosenberg only briefly mentions the importance to litigants of such subsidiary legal rules, ${ }^{44}$ and he fails systematically to exploit the historical implications of the insight.

Rosenberg's distaste for doctrine also constrains the kinds of interpretive hypotheses he is able to offer. Doctrine is an important means by which legal purposes are articulated and implemented. Taking doctrine seriously thus implies viewing the law from an internal perspective, from the standpoint of someone who accepts the practices of the law as a legitimate and

originally publishes it. Thus if the President calls a certain individual corrupt, the press can be liable for repeating the accusation. The privilege of neutral reportage is meant to shield the press from such liability, and hence to protect its ability to report on important and sometimes bitter public disagreements, even if the press lacks independent knowledge concerning the truth of the underlying defamation. In this sense the privilege is an attempt to acknowledge the difference between the modern press and "the village gossip . . . [of] two hundred years ago." See note 26 supra.

40. Although the precise distinction between libel per se and libel per quod varies from state to state, in general libel per se is a written communication whose defamatory content is patent on its face, while libel per quod is a communication that only becomes defamatory when understood in the light of extrinsic facts. An example of the former would be a newspaper story to the effect that "John is an adulterer"; an example of the latter would be a local newspaper announcement to the effect that "John will marry Jane," when the entire community knows that John is already married to Mary. Since damages are more difficult to establish for libel per quod than for libel per se, the distinction should be understood as a recognition that the press cannot, like a village gossip, be viewed as a member of a community with implicit knowledge of all pertinent background facts. As Cooley recognized, technological innovations in the transmission of information have caused the press to receive and communicate information to many different communities concerning which it can have no such intimate knowledge. See note 26 supra. For a sampling of the controversy surrounding the distinction between libel per se and libel per quod, see Prosser, Libel Per Quod, 46 Va. L. Rev. 839 (1960); Henn, Libel-by-Extrinsic Fact, 47 Cornell L.Q. 14 (1961); Eldredge, the Spurious Rule of Libel Per Quod, 79 Harv. L. Rev. 733 (1966); Prosser, More Libel Per Quod, 79 Harv. L. Rev. 1629 (1966); Eldredge, Variation on Libel Per Quod, 25 Vand. L. Rev. 79 (1972).

41. S. Greenleaf, 2 A Treatise on the Law of Evidence $\S 419$ (2d ed. 1848).

42. S. Greenleaf, 1 A Treatise on the Law of Evidence $\$ \S 329-30$ (2d ed. 1844).

43. J. Wigmore, $1 \mathrm{~A}$ Treatise on the Anglo-American System of Evidence in Trials at Common Law $\S \S 70-74$ (3d ed, 1940).

44. See, e.g., Rosenberg at $122,139$. 
serious manner of expressing social purposes and attaining social ends. ${ }^{45}$ But Rosenberg is reluctant to adopt this perspective. $\mathrm{He}$ is much more comfortable either reviewing public debates about political libel and assessing the contributions of intellectuals like George Hay or Frederick Grimke, or attributing the law of political libel to impersonal social forces like the emergence of the institutional press or the changing nature of political parties. The first of these approaches assimilates law into the context of general political culture; the second flattens law into simply another parameter of social history. ${ }^{46}$ Rosenberg amply demonstrates the valuable insights that each of these approaches can yield, and yet both approaches essentially deny the independence of law as an instrument of human purpose. What is lost is the history and drama of specifically legal attempts to create social meaning.

One can readily sympathize with Rosenberg's dilemma. The most striking fact about political libel is the stability of its major doctrinal framework in the face of vast changes in political culture and social structure. It is no wonder that in the context of such an apparent anomaly Rosenberg would come to view doctrine as simply a repository of arid and abstract rules, unconnected to purposeful action. But holding this view blinds Rosenberg to inquiries he might otherwise undertake, and it renders invisible potentially pertinent historical evidence.

For example, although Rosenberg attributes to "[d]efamation doctrines" the ambition of expressing "one of the central tenets of liberal society: the supposedly clear separation between the public and private spheres," he does not develop this insight, choosing instead to defiate the pretension of "jurists" that "trained legal minds could . . . use legal doctrines to demarcate" these spheres (at 267). But while Rosenberg's point is well taken that the distinction between "public and private spheres" is not carved immutably in tablets of legal reason, the point distracts him from the more central insight that the law's separation of "public" and "private" is itself intentional human action requiring explanation. Rosenberg neither adopts an internal perspective nor inquires after the meaning or social purposes of the doctrinal distinction. At some level he recognizes that doctrine is "a means of disseminating messages about the general nature of American society" (at 267), but he never pauses carefully to consider the nature of the messages conveyed. Thus he does not systematically explore the distinctions that have in fact been drawn between "public and private spheres," nor does he attend closely enough to the philosophical or sociological un-

45. For a discussion of the distinction between "internal" and "external" perspectives, see H.L.A. Hart, The Concept of Law 55-57 (1961); R. Dworkin, Law's Empire 13-15 (1986); A. MacIntyre, After Virtue 175-89 (1981).

46. One serious weakness of Protecting the Best Men is that Rosenberg offers only anecdotal evidence of actual libel litigation. He provides neither detailed narratives of particular libel cases, nor statistical evidence of exactly who was suing whom, over what kinds of issues, and with what outcomes. As a result the hard data that might have confirmed many of Rosenberg's historical interpretations are simply not available. 
derpinnings of these distinctions to explore how they might be understood as purposeful responses to changing conditions. He considers it sufficient simply to demonstrate that such distinctions have been inconsistently applied.

The limitations of Rosenberg's approach are most glaring in his discussion of the unsettled period after New York Times, when the doctrinal framework of political libel has been in a state of rapid and profound flux. This has been a period of legal experimentation, as well as of a rich and fascinating literature concerning potential directions for the law. But because Rosenberg tends to dismiss doctrine, his attitude toward these developments is one of airy insouciance: he chooses to address underlying institutional changes and to leave doctrinal games to the lawyers. But this is a little bit like writing a history of French literature while refusing to learn French. Doctrine, like French, is a language expressive of human purposes and intentions, and if that language remains unintelligible, so does much the most interesting part of the history of political libel.

\section{III}

Viewing doctrine as a language creates a particular kind of agenda for the historian, for it requires him or her to inquire after doctrine's meaning. This meaning can be illuminated by social history or by the actual impact of a doctrinal rule, but it cannot be reduced to these things. Neither is it synonymous with authorial intention or with the understanding of a specific audience. The meaning of doctrine, like the meaning of any other use of language, is best discerned by a patient respect for what the relevant text has to tell us when questioned in the light of our contemporary concerns.

The historical rewards of thinking about doctrine in this way can be illustrated by a close study of the New York Times decision itself. It is often said that the special virtue of New York Times was that it restored "seditious libel to its essential role . . . as the key to the meaning of the First Amendment." 47 New York Times fused the issues of defamation and sedition by holding that criticism of the government was for First Amendment purposes indistinguishable from criticism of individual government officials. The "uninhibited, robust, and wide-open" character of this criticism would be dampened if it could be penalized by defamation law. Not that untrue statements of fact have inherent First Amendment value, ${ }^{48}$ but individuals may well be deterred from making accurate assertions because of the possibility of unexpected error, or because of the expensive, complex, and unpre-

\footnotetext{
47. Kalven, The New York Times Case: A Note on "The Central Meaning of the First Amendment," 1964 Sup. Ct. Rev. 191, 204.

48. Since truth is a complete defense to the tort of libel, civil defamation suits penalize only false communications. Although for a brief moment in 1964 Justice Brennan was willing to take the position that "honest utterance, even if inaccurate, may further the fruitful exercise of the right of free speech," Garrison v. Louisiana, 379 U.S. 64, 75 (1964), the Court soon retreated from this position and explicitly held that "there is no constitutional value in false statements of fact." Gertz v. Robert Welch, Inc., 418 U.S. 323, 340 (1974). See St. Amant v. Thompson, 390 U.S. 727, 732 (1968).
} 
dictable process of proving truth in a court of law. The "actual malice" test was designed to accomplish a precise task, which was to distinguish and isolate those false factual communications that could be sanctioned without chilling protected speech. By penalizing only the individual who actually "entertained serious doubts as to the truth of his publication,"49 the Supreme Court sought to remove the fear of careless error or the apprehension created by the uncertainties involved in legal determinations of truth.

Almost every step of this reasoning carries with it sighificant historical interest. Consider, for example, the use of the concept of seditious libel to define an arena of protected First Amendment speech. In 17th- and 18thcentury England reputation was often bound up with the ascribed social status of an individual's particular position in society. ${ }^{50}$ The common law of defamation evolved to protect this status, ${ }^{51}$ and hence in the eyes of the law a libel "against a magistrate, or other public person" was viewed as a "greater offence" than a libel "against a private man." 52 The crime of seditious libel, which during this time gradually came to encompass defamation against the government as well as against individuals, ${ }^{53}$ epitomized this focus on the safeguarding of status. As one early 19th-century commentator put it, "The offence of libel and slander is proportionately more criminal as it presumes to reach persons to whom special veneration is due. The diminution of their credit is a public mischief, and the state itself suffers in their becoming objects of scorn." 54

In post-revolutionary America, however, where there was great resistance to the use of defamation law to protect status, ${ }^{55}$ this link between seditious libel and private defamation was severed. ${ }^{56}$ In the great majority of states that rejected Cooley's proposed conditional privilege, defamation against a public official was actionable not to shield the status of the office, but rather to protect the precisely private reputation of the officeholder. The standard justification for applying the ordinary rules of defamation to political figures was that "a person who enters upon a public office, or be-

49. St. Amant v. Thompson, 390 U.S. at 731. See note 6 supra.

50. H. Perkin, The Origins of Modern English Society 1780-1880, at 24-25 (1969); L. Stone, The Crisis of the Aristocracy 21 (1965).

51. See Post, The Social Foundations of Defamation Law: Reputation and the Constitution, 74 Cal. L. Rev. 591, 699-707 (1986).

52. 3 De Libellis Famosis, 3 Coke's Reports 254, 255 (pt. v, fol. 125) (1605). As Blackstone later put it, words that "would not be actionable in the case of a common person, yet when spoken in disgrace of . . . high and respectable characters . . . amount to an atrocious injury." W. Blackstone, 3 Commentaries on the Laws of England 123 (1768).

53. Hamburger, The Development of the Law of Seditious Libel and the Control of the Press, 37 Stan. L. Rev. 661, 735-36 (1985).

54. F. Holt, The Law of Libel 90 (1816).

55. The reputation protected by defamation law was instead most apt to be conceptualized as "a property . . . which must be purchased" by the efforts required to acquire a good name. James Wilson, Lectures on Law in 2 The Works of James Wilson 595 (Robert McCloskey ed. 1967).

56. For this reason the Jeffersonians, as Rosenberg points out, could vigorously repudiate the crime of seditious libel and at the same time accept the exaction of crushing civil damages in "compensation" for damage to the private reputation of public officials. Rosenberg at 93-96. 
comes a candidate for one, no more surrenders to the public his private character than he does his private property." 57

In New York Times these developments came full circle. As in the 17th century, the importance of the office was paramount, but in New York Times this importance was perceived as justifying the expropriation of the private character of the officeholder: to make it, "as it were, public property."58 Seditious libel was used as a measure of protected, rather than of prohibited, speech, and the conceptual connection between seditious libel and private defamation was provided by New York Times's functionalist perspective, which viewed penalizing certain kinds of private defamation as having the same "effect" as suppressing public criticism of the government. In the end, therefore, what ultimately distinguished New York Times from preceding cases was the influence of American instrumentalism. ${ }^{59}$

Instrumentalism, however, requires doctrine to distinguish itself from customary social norms and mores. For this reason the effect of New York Times was to mark off a separate arena of public discussion in which the ordinary rules of civility, as defined and enforced by common law defamation, were suspended. Prior to New York Times most states dimly acknowledged a similar kind of arena by creating a privilege for defamatory statements of opinion, as opposed to defamatory statements of fact, which were about "matters of public concern,"60 including "the public conduct" of public officials. ${ }^{61}$ It is important to recognize, however, that this privilege carried within it a strong normative sense of the proper spirit in which public discussion should be conducted. The privilege could be lost, for example, if the defamatory opinion was published "solely for the purpose of causing harm to the other," or if it did not represent "the actual opinion of the critic." 62

States such as Kansas that adopted the conditional privilege for false statements of fact advocated by Cooley demonstrated a somewhat sharper sense of a distinct arena of political discussion. But those states also shared the belief that this arena was suffused with its own normative rules of participation. The conditional privilege could be defeated by a showing of common law malice, which could mean far more than that a defendant had acted from simple ill will or hostility. It could also mean that a defendant had "abuse[d] the occasion" for which his speech was privileged. 63 Thus

57. Post Publishing Co. v. Moloney, 50 Ohio St. 71, 89, 33 N.E. 921, 926 (1893).

58. New York Times Co. v. Sullivan, 376 U.S. at 268 (quoting Beauharnais v. Illinois, 343 U.S. 250, 263-64 (1952)). The metaphor is an old one. In 1818, for example, the Supreme Court of South Carolina, in discussing the problem of defamation of candidates for public office, stated that such candidates were "a species of public property." Mayrant v. Richardson, 1 Nott \& McCord 347, 350 (S.C. 1818).

59. See R. Summers, Instrumentalism and American Legal Theory (1982).

60. Restatement of Torts $\S 606$ (1938).

61. Id. at $\S 607(1)$.

62. Id. at $\S 606$.

63. Id. at $\S 599$. See L. Eldredge, The Law of Defamation $\$ \S 93-94$ (1978). The Restatement elaborated the meaning of an "abuse of an occasion": "The unreasonable exercise of the privilege is an abuse of the occasion which defeats the protection otherwise afforded. The occasion may be abused because of 
the conditional privilege for political libel could be lost if false statements of fact were published "from interested motives,"64 or were not uttered "in good faith in a sincere effort to apprize the electors of defendant's fitness for" office. ${ }^{65}$ Malice marked the line of demarcation between approved and disapproved forms of political participation.

The arena of political discussion delineated by New York Times represented a radical break with this tradition, for it did not embrace normative rules of participation within its very definition. Unlike common law malice, the constitutional malice proposed by New York Times made no effort to embody and enforce a boundary between morally acceptable and unacceptable modes of political discussion; instead the "actual malice" test was designed solely as an instrument of policy, to attain the specific end of minimizing the chill on legitimate speech. ${ }^{66}$ For the sake of achieving this goal New York Times was prepared to require that normatively repugnant forms of political discussion be tolerated. To make this point clear, the Supreme Court was forced repeatedly to emphasize the distinction between constitutional and common law malice, stressing that even false defamatory speech uttered "from personal spite, ill will or a desire to injure" the plaintiff does not by that fact amount to constitutional malice. ${ }^{67}$

The distinction was even reflected in the procedures that surrounded the two forms of malice. Because common law malice embodied the community's sense of appropriate political discussion, it was at common law viewed as a question of fact to be decided by a jury, the representative of the community. But because the Supreme Court viewed constitutional malice as a tool of judicial policy, it understood the question of actual malice to involve a "constitutional fact" as to which judges must conduct "independ-

the publisher's lack of belief or reasonable grounds for belief in the truth of the defamatory matter; because the defamatory matter is published for some purpose other than that for which the particular privilege is given; because the publication is made to some person not reasonably believed to be necessary for the accomplishment of the purpose of the particular privilege; or because the publication includes defamatory matter not reasonably believed to be necessary to accomplish the purpose for which the occasion is privileged." Restatement of Torts at $\$ 599$, comment a.

64. MacLean v. Scripps, 53 Mich. 250, 18 N.W. 209, 210 (1884)(per Cooley, J.).

65. Good v. Higgins, 99 Kan. 315, 161 P. 673, 675 (Kan. 1916).

66. As the Court said four years later in St. Amant v. Thompson, 390 U.S. 727, 731-32 (1968):

It may be said that [the actual malice] test puts a premium on ignorance, encourages the irresponsible publisher not to inquire, and permits the issue to be determined by the defendant's testimony that he published the statement in good faith and unaware of its probable falsity. . . . But New York Times and succeeding cases have emphasized that the stake of the people in public business and the conduct of public officials is so great that neither the defense of truth nor the standard of ordinary care would protect against self-censorship and thus adequately implement First Amendment policies. Neither lies nor false communications serve the ends of the First Amendment, and no one suggests their desirability or further proliferation. But to insure the ascertainment and publication of the truth about public affairs, it is essential that the First Amendment protect some erroneous publications as well as true ones.

Of course it was always open to the Court to adopt the line urged by Justices Black and Douglas, and to prohibit all liability for political defamation. From this perspective the actual malice test does penalize some morally unacceptable forms of political speech. But the point is that the actual boundary drawn by the test is not dictated by such moral concerns, but is rather responsive to specific and explicit First Amendment policies.

67. Beckley Newspapers v. Hanks Corp., 389 U.S. 81, 82 (1967). 
ent review"68 to assure that a judgment of liability "does not constitute a forbidden intrusion on the field of free expression." 69

The shift in emphasis from the jury to the judge corresponds to New York Times's altered perception of political discussion. While it is no doubt going too far to equate the "uninhibited, robust, and wide-open" public debate celebrated by New York Times with the "malignant, vulgar, and mendacious" debate bewailed by Jefferson, it is nevertheless clear that the aim of the actual malice test was to liberate political discussion from common rules of civility and decency. Although as a practical matter public debate had always tended to violate such rules, defamation law's traditional treatment of political libel evidenced a strongly felt need authoritatively to disapprove of these violations. Throughout most of our cultural history, as the Supreme Court recently observed, "the habits and manners of civility" were deemed "indispensable to the practice of self-government in the community and the nation."70 The question, then, is how we are to understand New York Times's abandonment of this normative standard, an abandonment that has now become so controversial.

Several different lines of inquiry suggest themselves. One concerns the influence of instrumentalism on American law. Instrumentalism appears to weaken the connection between doctrine and ordinary moral apprehension, and for this reason one would expect it to have a significant impact on our conception and practice of law. But although the influence of instrumentalism has widened and deepened, the sociological origins and implications of this influence have yet to be assessed. New York Times and its history represent an excellent occasion for such an evaluation.

A second line of inquiry might focus on the process of massive cultural nationalization that occurred during the 1960s. As Rosenberg recognizes, New York Times was clearly part of the national effort to extinguish the local culture of southern apartheid." In this sense the "actual malice" test was designed as an instrument of centralized control specifically to prevent defamation law from being used to implement local cultural mores. Whether such imperviousness to "the habits and manners of civility" is a necessary concomitant of national control in a nation as large and diverse as the United States, is a rich and provocative historical question.

68. Bose Corp. v. Consumers Union of U.S., 466 U.S. 485, 498-511 (1984).

69. New York Times Co. v. Sullivan, 376 U.S. at 285.

70. Bethel School Dist. v. Fraser, 106 S. Ct. 3159, 3164 (1986).

71. In New York Times a commissioner of Montgomery, Alabama, sued the New York Times over an advertisement placed in the paper by the "Committee to Defend Martin Luther King and the Struggle for Freedom in the South." The advertisement was factually inaccurate in certain trivial respects, and yet it was the basis for suits by five Alabama officials seeking \$3 million in damages. The suits were part of a general campaign by southerners to use defamation law to suppress criticism of southern racism. See Lewis, Annals of Law: The Sullivan Case, New Yorker, Nov. 5, 1984. The Supreme Court's decision in New York Times was part of a more general northern determination to overcome such southern resistance. 
A third line of inquiry, no doubt in some tension with the first, might entail an examination of the general tendency of the Court during the 1960 s and 1970 s to protect the value of individual autonomy. ${ }^{72}$ Although this tendency received exemplary expression in cases like Roe $v$. Wade, ${ }^{73}$ it was also perceptible in the First Amendment area in such decisions as Cohen $v$. California ${ }^{74}$ and Wooley v. Maynard. ${ }^{75}$ The value of autonomy, of course, emphasizes the importance of individual "self-direction,"76 of the freedom "to choose whether to conform or not" to society's behavioral norms. ${ }^{77}$ In its legal aspect, the value might be summarized as "the right to differ as to things that touch the heart of the existing order."78 New York Times's use of the First Amendment to constitutionally prohibit enforcement of "the habits and manners of civility" is in this sense consonant with the value of autonomy, for it liberates individuals to debate public subjects in a manner that is to a significant degree unconstrained by common rules of decency or propriety.

To view New York Times as reflecting the value of autonomy would require revising our understanding of the case, for the opinion has traditionally been interpreted as exemplifying the analytic framework associated with Alexander Meiklejohn. ${ }^{79}$ This framework emphasizes the supreme importance in a democracy that all pertinent political ideas and information be available to the electorate. It thus focuses on "the minds of the hearers" rather than on the autonomy of speakers. ${ }^{80}$ But while it is clear that Meiklejohn's thinking strongly influenced the reasoning of New York Times, the limits of this influence have not always been noticed.

Meiklejohn built his theory around the image of "the traditional American town meeting," which he regarded as "a model by which free political procedures may be measured."81 For Meiklejohn a town meeting was "not a Hyde Park." It was instead "a group of free and equal men, cooperating in a common enterprise, and using for that enterprise responsible and regulated discussion." The goal of the enterprise was not "that everyone shall speak, but that everything worth saying shall be said." To accomplish this purpose, political speech had to be regulated by strict rules of order and decorum. "If a speaker wanders from the point at issue, if he is abusive or

72. See Smith, The Constitution and Autonomy, 60 Tex. L. Rev. 175 (1982).

73. 410 U.S. 113 (1973) (creating a constitutional right to an abortion).

74. 403 U.S. 15 (1971) (constitutionally prohibiting a state from punishing an individual for displaying the phrase "Fuck the Draft" on his jacket).

75. 430 U.S. 705 (1977) (constitutionally prohibiting a state from requiring a Jehovah's Witness to display the motto "Live Free or Die" on his license plate).

76. S. Lukes, Individualism 52 (1973). See I. Kant, Groundwork of the Metaphysic of Morals (H. J. Paton trans. 1964).

77. D. Riesman et al., The Lonely Crowd: A Study of the Changing American Character 242 (1961).

78. West Virginia State Board of Education v. Barnette, 319 U.S. 624, 642 (1943).

79. Brennan, The Supreme Court and the Meiklejohn Interpretation of the First Amendment, 79

Harv. L. Rev. 1 (1965); L. Bollinger, The Tolerant Society 46-50 (1986).

80. A. Meiklejohn, Political Freedom: The Constitutional Power of the People 26 (1948).

81. Id. at 24 . 
in other ways threatens to defeat the purpose of the meeting, he may be and should be declared 'out of order.' "\$2

While New York Times embraced Meiklejohn's goal that "everything worth saying be said," it abandoned his concomitant emphasis on the importance of rules of order and civility to the attainment of that goal. New York Times chose to prohibit the government from acting as the moderator of a civic town meeting. This choice was neither practically nor legally compelled. As Justice White has recently pointed out, New York Times could have attempted to minimize the chill on protected speech by restricting allowable damages rather than by altering liability rules. ${ }^{83}$ It seems no accident that New York Times chose to attain its goal in a manner consistent with the value of individual autonomy, a value that at the time was in the process of becoming a central theme of the Court's constitutional jurisprudence. ${ }^{84}$ The influence of autonomy became explicit eight years later, when in Gertz v. Robert Welch, Inc. ${ }^{85}$ the Court held that even in those situations where defamatory communications were not about public figures and did not involve matters of public concern, the First Amendment nevertheless prohibited states from imposing liability without fault. This holding simply cannot be explained within a Meiklejohnian framework.

It is perhaps a sign of the waning influence of the value of autonomy that the Court has recently signalled that Gertz will be reinterpreted so as to limit its requirement of fault to those defamatory communications involving issues "of public concern," a position completely compatible with traditional Meiklejohnian analysis. ${ }^{86}$ In defending Gertz's original holding, Justice Brennan has been pushed to ground his reasoning explicitly in the value of autonomy:

“. . . [O]ur cases have never suggested that expression about philosophical, social, artistic, economic, literary, or ethical matters-to take a nonexhaustive list of labels-is not entitled to full First Amendment protection." [Abood v. Detroit Bd. of Educ., 431 U.S.,] at 231. The breadth of this protection evinces recognition that freedom of expression is not only essential to check tyranny and foster self-government but also intrinsic to individual liberty and dignity and instrumental in society's search for truth. See . . Whitney v. California, 274 U.S. 357,375 (Brandeis, J., concurring). ${ }^{87}$

82. Id. at 24-26.

83. Dun \& Bradstreet, Inc. v. Greenmoss Builders, 472 U.S. 749, 771 (1985) (White, J., concurring).

84. See Smith, note 72 supra. Another way of putting this is that New York Times chose to exercise the instrumental option that was most consonant with the value of autonomy rather than the option that was more closely connected with the value of civility.

85. 418 U.S. 323 (1974).

86. See Dun \& Bradstreet, Inc. v. Greenmoss Builders, 472 U.S. 749 (1985). Cf. Philadelphia Newspapers v. Hepps, $106 \mathrm{~S}$. Ct. 1558 (1986). The Court has not clarified the relationship between the First Amendment's definition of "public concern," and the common law definition of "public concern." See note 60 supra.

87. Dun \& Bradstreet, Inc. v. Greenmoss Builders, Inc., 472 U.S. at 787 (Brennan, J., dissenting). 
At the present time, however, the Court remains unmoved by this appeal to intrinsic individual "dignity."

The ebb and flow of the value of autonomy is of course a historical phenomenon that itself requires interpretation. One hypothesis is that it is related to changing attitudes toward the cultural nationalization which was so characteristic of the 1960s. Another is that the withering attack on the legitimacy of local and national institutions during the 1960s and 1970s created a climate that fostered a belief in individual autonomy. Undoubtedly further inquiry would yield numerous other hypotheses. The point, however, is that the inquiry cannot even begin unless one takes seriously the doctrine of New York Times as an attempt to create a world of social meaning.

When viewed in this light the history of the law of political libel will likely prove a rich and illuminating historical resource, telling us much about our concepts of politics, civility, and law. It is a resource that would benefit us all if quarried by talented historians like Rosenberg. But just as historians feel free (perpetually) to criticize lawyers' instinctive misuse of history, so lawyers should be entitled to remark on historians' lack of spontaneous appreciation for the internal dynamics of the law. It is a good occasion to urge better understanding between the disciplines. 
HeinOnline -- 1987 Am. B. Found. Res. J. 5581987 